\title{
INDIGENOUS: IT DEPENDS HOW YOU LOOK AT IT. WHAT YOU CALL IT. HOW YOU LIVE IT
}

\author{
Laura Beard \\ University of Alberta, Canada \\ Daniel Hopkins ${ }^{* \star}$ \\ Texas Tech University
}

\begin{abstract}
In this article, we use examples from contemporary Anishinaabe artist Rebecca Belmore and the works of the Spiderwoman Theater Troupe to explore how contemporary Indigenous artists in the Americas negotiate the representation of Indigenous identities, identities which are always performed and entangled in a mesh of geographical locations, cultural practices and ideological borders. Through their artistic productions, many Native artists and authors participate in a larger community of voices discussing what it means to be Indigenous in the Americas and what ethical responsibilities or commitments to community are entailed in and by their work.
\end{abstract}

Keywords: Indigenous; identity; Spiderwoman Theatre; Rebecaa Belmore; performance.

America: it depends how you look at it. What you call it. How you live it. Diana Taylor

In "Remapping Genre through Performance: From 'American' to 'Hemispheric' Studies,' Diana Taylor discusses how she came to understand the complexities of being "a citizen of the Americas and a scholar of hemispheric studies," in a geography and a discipline she refers to as an "undisciplined and ungovernable body of knowledge and relations organized around the oddly shaped landmass misidentified, mislabeled, and misrepresented from the moment of first European explorations" (1416). Taylor's discussion of a shared hemispheric reality of "tangled systems of expression, representation, and economic and power relations" in which trying to understand identities themselves entangled with geographical locations, cultural practices, naming practices and "heavily policed ideological borders" make both lives and scholarship a challenge (1417) is of interest not just for scholars in performance studies but for all of us working in Inter American Studies or hemispheric studies.

We borrow a sentence from Taylor, but re-focus it, moving from "America" to "Indigenous." For within that oddly shaped landmass of the Americas, arguably the most "misidentified, mislabeled, and misrepresented" of all are Indigenous peoples. In our brief article, we take up the examples of Rebecca Belmore and Spiderwoman Theatre to explore how contemporary Indigenous artists in the Americas negotiate the representation of Indigenous identities, identities which are always performed and entangled in a mesh of geographical locations, cultural practices and ideological borders.

As Jace Weaver notes, "Native peoples have never recognized the arbitrarily drawn borders that demarcate the modern nation-states of the Americas"

\footnotetext{
* Laura J. Beard is Professor and Chair of the Department of Modern Languages \& Cultural Studies at the University of Alberta, Canada, where she is also an Adjunct Professor in the Faculty of Native Studies. Her research and teaching interests include women writers of the Americas, life narratives, and Indigenous literatures and cultures. E-mail: lbeard@ualberta.ca

${ }^{* *}$ Daniel Hopkins lived in the Guna community of Uggubseni, Panama, for two years before receiving his Ph.D. in Spanish from Texas Tech University with a focus on contemporary Latin American Literature. His research interests include the literature of Central America with an emphasis on indigenous literatures and migrations. He has an article entitled "Molas, Corn Flakes and a Lonely Hearts Club: Expressions of Guna Identity in Two Works by Arysteides Turpana and Aiban Wagua” forthcoming in Latin American Indian Literatures Journal. E-mail: Daniel.Hopkins@ttu.edu.
} 
(xi). That Thomas King (Cherokee), E. Pauline Johnson (Mohawk), Peter Jones (Anishinaabe) and George Copway (Anishinaabe) and others have been claimed as part of the national literatures of both Canada and the United States shows that Native literature does indeed cross borders (Weaver 23). Many of the concerns taken up in the works of Indigenous authors and artists cross borders as well, shared political concerns with retaining land, recovering lost territories, self-governance, cultural maintenance, revitalization, and sovereignty, all elements Kathryn Shanley delineates as part of "belonging to a place, a homeland" (3).

Through their artistic productions, many Native artists and authors participate in a larger community of voices discussing what it means to be Indigenous in the Americas in the present day. Community and identity are always already intertwined for Indigenous peoples: Vine Deloria reminds us that "Indian tribes are communities in fundamental ways that other American communities and organizations are not. Tribal communities are wholly defined by family relationships, whereas non-Indian communities are defined primarily by residence or by agreement with sets of intellectual beliefs" (75-76). Acoma Keres Pueblo author Simon Ortiz also sees Indigenous identity as being "relevant and pertinent to ... elements and factors having to do with land, culture, and community of Indigenous people" ( xi). Ortiz reminds us that:

Throughout the Americas, issues and concerns about land, culture, and community abound, especially where Indigenous communities have resisted physical removal and annihilation, destructive assimilation and acculturation, and the outright loss of land, resources, and human capital. This means that Indigenous people have completely relied upon their Indigeneity to state their cause for sovereignty intercultural and selfgovernance matters. "Indians are still Indians" is not an empty statement but a basic assertion and stand in securing the rightful position they have as human beings. (xii)

Ortiz asserts the responsibilities that Indigenous authors have to write literature that adequately and appropriately represents Indigenous peoples (xiii).
For contemporary Indigenous artists, part of that appropriate representation is an exploration of what it means to be Indigenous, what they call it, how they live it, and how it may entail a commitment to that sense of community. Cherokee critic Jace Weaver coined the word "communitist" to refer to Native literature, asserting that "literature is communitist to the extent that it has a proactive commitment to Native community, including the wider community. In communities that have too often been fractured and rendered dysfunctional by the effects of more than 500 years of colonialism, to promote communitist values means to participate in the healing of the grief and sense of exile felt by Native communities and the pained individuals in them" (43).

For the Guna people of Panama, coming together as a community is played out in the tradition of igariddoged. Igariddoged comes from the word "igar," which means way, path, street, lesson or agreement. Igar is also a healing chant. The word "iddoged" also has several meanings including: "to listen, to hear, to taste, to perceive, to feel, to understand, to try a food"; as a noun it also means "week" (Oran and Wagua 57). An "igaridogged" is a meeting or a gathering of people to discuss different matters that can range from an informal meeting of a group within the community to a meeting of the entire community or a collection of communities known as a gathering or "congreso" in Spanish (Oran and Wagua 57). Men and women meet daily in the "iddogednega" or the gathering house to discuss important issues, to make decisions and to settle disputes.

The works of the Spiderwoman Theater Troupe can be read in the context of an igariddoged, a gathering of people listening to life lessons, perceiving paths to understanding and discussing ways to heal. Founded in 1976 in New York City, Spiderwoman Theater is a collective that sprang out of the feminist movement of the 1970s and by the 1980s had become recognized as a powerful voice for the concerns of Indigenous women. Their stated mission is "to present exceptional theatre performance and to offer theater training and education rooted in an urban Indigenous performance practice." The Spiderwoman Theater troupe is made up of various members but their acknowledged core is formed by the three sisters of Guna and Rappahannock descent, Lisa 
Mayo, Gloria Miguel and Murielle Miguel. The three sisters were born in Brooklyn, New York, to Antonio and Elmira Miguel, and, as they note on their website, "their work springs from their own lives and experiences as 'city Indians."' (http://www.spiderwomantheater.org/ SpiderwomanAboutUs.htm).

A quick review of the family origin of the Miguel sisters, taken from a 1992 interview with Lisa Mayo by Judy Burns and Jerri Hurlbutt titled "Secrets: A Conversation with Lisa Mayo of Spiderwoman Theatre," highlights how their own family story is an example of those "tangled systems of expression, representation, and economic and power relations" cited by Taylor. Their mother Elmiras family is from Virgina and is part of the Rappahannock community, descending from the Powhatan alliance, while their father Antonio's family came from Narganá, in what is now the Comarca Kuna Yala, in Panama. Yet, like so many Indigenous children throughout the Americas, Antonio did not have the opportunity to spend his entire childhood in his Native community. At age six, he was adopted by a British family and taken to the West Indies to receive an education. He did not adjust well, and was returned to Narganá, where, at the age of 15 , he began to work on merchant vessels. During a leave in New York City, he met Elmira. The couple was engaged, but Antonio returned to Narganá. Elmira waited for him for three years and, as the family story is told, used her knowledge of traditional Rappahannock medicine to bring him back to her. While in Narganá, Antonio's family had arranged him to be married to a Guna woman, but he did eventually return to New York and marry Elmira. Thus, their family story is one of dislocation and displacement, of unequal economic and power relations, but also one of powerful love and family relationships.

In this article, we focus on the drama Nis Bundor: Daughters from the Stars (1995), a production that focuses on Lisa Mayo's and Gloria Miguel's preparations for and trip to the Comarca Kuna Yala in 1994. The drama charts their journey to reunite with their father's side of the family and deal with their own tangled identity issues after their father's immigration to the United States. In a drama interspersed with scenes that discuss bringing people together from all over the Americas, remembering ancient paths, honoring women in society, and breaking enchantments, the effort to understand identities entangled with geographical locations, cultural practices, and heavily policed ideological borders is clearly underscored. These disparate scenes are then sewn together with the retelling of Guna oral history of a woman named "Olonadili" and her three other sisters who came down from the stars. Nis Bundor can be read as Spiderwoman Theater's creation of a dramatic mola in an international igariddoged, one in which they add their voices with those of other Indigenous writers gathered to discuss Indigenous identities in an ever-changing world.

The Miguel family story recalls stories of many Guna who have left the Comarca Kuna Yala. Today, more than half of the Guna population lives outside of the Comarca Kuna Yala. Many Guna families and communities, while experiencing dispersal, migration and movement from their homeland, still hold onto collective memories of the homeland. For as renowned Mvskoke poet Joy Harjo has written about her own homeland in "Oklahoma: The Prairie of Words," the homeland becomes both the physical place (the red earth of Oklahoma for Harjo or the lands of the Comarca Kuna Yala for the Guna peoples) and the dream kept alive inside:

What Oklahoma becomes, in a sense, is a dream,
an alive and real dream that takes place inside and
outside of the writer. Our words begin inside of
the dream. Living voices surround us and speak
from the diverse and many histories that we
have been. The stories and poems are in motion
within the red earth-which has the boundaries
that dreams have. (qtd. in Fast 1999:3)

For Harjo, Oklahoma is the place of dreams, poems, and stories, as well as the red earth on which she walks.

For the women of Spiderwoman Theater, the Comarca Kuna Yala is the place of dreams, poems and stories, as well as both the stage on which they perform and the earth on which their Guna relatives walk. During the drama Nis Bundor, an audiotape is played for the audience telling the story of Antonio Miguel leaving a wife and infant son in his hometown in Panama to marry a Rappahannock woman in the United States. Together, he and the Rappahannock woman had three daughters 
and every night he would sing a lullaby to them about the Daughters who came down from the Stars (from a traditional Guna story of Olonadili ${ }^{1}$ ). Although Antonio never returned to Guna Yala, the audiotape mentions that Antonio's two eldest daughters decided to return to break the strong enchantment working in their lives and "the conflicting worlds in which they live joined" (Nis Bundor 8:15). In this recorded audiotape, it is explained that the Daughters from the Stars, like Lisa Mayo and Gloria Miguel, work together to break an enchantment that has divided their lives into two worlds: Guna Yala and the United States. Thus, migrations, contacts and conflicts between worlds and overcoming the powers that divide people are at the heart of both the traditional Guna story of "Olanadili" and the contemporary story in Nis Bundor.

While Nis Bundor tells the very personal story of the Miguel Sisters, at the same time it is a story that Mayo and Miguel hoped would speak to other people with similar life experiences. In an interview with the members of Spiderwoman Theater conducted by Larry Abbot entitled "Spiderwoman Theatre: The Tapestry of Story" (1996), Miguel and Mayo talk about the origins of the drama Nis Bundor. Miguel mentions in that interview that she wished to combine a previous solo project she did with "the voice of the people from Kuna Yala" (177). Mayo added in that interview that in the drama, "Were bringing the information from the Kunas to North America and from North American tribes down there. That's part of it. The other part is, well, it's to make yourself whole" (178). In this manner Nis Bundor was conceived as a way for the Miguel Sisters to talk about their Guna identity, to reconnect to their heritage, and to share the stories of other Guna with Indigenous people living in different nation states.

The spirit of reconnecting to a Guna community in Nis Bundor is also achieved through multiple examples of verbal and visual arts that can be read and understood by people familiar with Guna communities. In the first scene, on stage Gloria Miguel tells the audience that: "We are gathered here tonight, in the presence of the moon, to bring and keep people together" (6:52). The stage then goes dark and a plurality of voices can be heard offstage conversing at the same time. The stage lights return to the scene of Gloria Miguel and Lisa Mayo performing a Guna dance while singing and playing maracas. Both of them are wearing molas. Although the majority of this scene is in English, the sisters sing the Guna phrases "an buna" (I am a daughter), "an be abege" (I love you), and "nabiri" (it is true) while dancing. The singing style is similar to the call and response chants of Pab Igar, sung in the iddogednega. The words "an buna" and "an be abege" amplify the feelings of family, love and unity for a person who understands the Guna language. The word "nabiri" is particularly salient, for it is often used in the context of storytelling for marking the end of a line in a story (Sherzer 112). Call and response as well as the repetition of "nabiri" help audience members to suspend disbelief and witness elements of an igariddoged in which community members listen to stories and find ways to heal. The onstage performance engages performers and audience members alike with the entangled questions of Indigenous identities throughout the Americas.

Nis Bundor also has a scene in which Gloria Miguel's character "Flies Far Jumping Woman" reminds the audience of ancient paths which stretch out across the Americas. Miguel speaks more of the creation of this character that she developed in an interview with Larry Abbot. Miguel notes that the character travels all over and is a composite of one character that: "jumps and tickles and kisses and wiggles her way into people's thoughts and minds and talks about herself, and wants to know about other people. This character, I put together with a character called Suriabad (sic) from Kuna Yala" (Abbot 177). A suaribed is a recognized authority of the iddogednega who carries an authority cane as he walks through the iddogednega during a chanting of a story from Pab Igala. During the chanting in the iddogednega, the suaribed will shout out "Gabidamalaye, nue balitomare" or "do not sleep, listen well!" Flies Far Jumping Woman takes on the role of suaribed in the theatre house, striking the cane on the stage during the production of Nis Bundor, telling the audience to "WAKE UP!" (40:35). The dramatic act awakens the audience seated in a theatre house in New York (The Empire State) to listen well to the stories from Indigenous men and women across the Americas and reconsider how Indigenous men and women have 
overcome repeated attempts from empires determined to divide and conquer them.

The stories that Far Flies Jumping Woman shares are not from Pab Igar but rather are stories of Indigenous peoples, from the Maya in Chiapas to the Cree in Canada talking about their lives and experiences. She speaks of her own conversations with Guna, who asked if there are still any Indigenous peoples living in North America, asking about what they look like and how do they live. Far Flies Jumping Woman declares: "Traders and scholars, traveling long distances up and down the Mississippi, passing from tribe to tribe, ideas, thoughts exchanging from family to family, skills, customs, relaying from hand to hand materials." The ancient paths that other people have traversed in the past are still important paths to walk today. She exclaims in Guna: "Nanaed, emisgine." She translates it for the audience as: "Let's walk together, right now" (Nis Bundor 45:45).

Neal McLeod, in Cree Narrative Memory: From Trends to Contemporary Times, speaks of Indigenous collective memory in terms of a shared space rather than a shared time: "It is the sense of place that anchors our stories; it is the sense of place that links us together as communities" (6). For Far Flies Jumping Woman, her travels reclaim vast distances of space from ancient paths in the collective memory in order to imagine Mapuches, Gunas, Mayas, and Cree all walking together, sharing stories and different ancient paths as she imagines North and South America as a space that has not been colonized or divided. The stories she shares reach across the borders of contemporary political nation states, and reconceptualize Indigenous communities not as solitary entities within the U.S., Canada, Mexico or Panama but as people coming together within a shared space.

While the stage and theatre in Nis Bundor come to represent an igariddoged: a gathering of people who share stories and paths to healing, onstage the characters played by Lisa Mayo and Gloria Miguel confront their fears and conflicts, imaging new ways to see themselves as Guna, as Rappahannock, as citizens of the United States and, ultimately, as a bridge that connects people crossing north and south through Indigenous America. Lisa Mayo and Gloria Miguel's characters express doubts about getting into a wobbly canoe to make their trip across the ocean back to their father's homeland in Kuna Yala. The memories of their immigrant father as an excellent swimmer and boat maker, however, give them the courage to board the canoe despite their own fears of drowning in a storm or being devoured by sharks. In the video recording of Nis Bundor, Lisa Mayo declares: "For the first time in my life, I can say I'm an ancient Guna Indian with Rappahannock blood. In a wheel chair, on a bridge I can say I'm an ancient Guna Indian with Rappahannock blood" (17:20). In this passage, the image that she creates for herself is multifaceted and powerful. Mayo claims a strong sense of identity here, knowing herself to be "an ancient Guna Indian with Rappahannock blood," yet it is also a liminal identity. In a wheel chair on a bridge, she occupies a position that crosses a boundary, yet no matter what boundaries she crosses, she is always Guna/Rappahannock.

The closing scenes of Nis Bundor present Gloria Miguel and Lisa Mayo as changed. They are jovial, laughing, smiling and singing together. They express pride at having completed the journey across the ocean, bridging the gap between their home in the United States and their father's home community in Panama. Onstage both Lisa Mayo and Gloria Miguel choose not to drink the traditional Guna cacao drink and ask their Guna hosts for Evian and Diet Coke. Upon reflecting on the elation of being "home" in the Comarca Kuna Yala, they harmonize together singing the song "Going Back to Texas." Together they sing onstage: "home, home, take me back to my good ol' Texas home, where your best friend is your bronco and your gun. Texas home my ramblin' days are done" (Nis Bundor). Two New Yorkers singing about going back to a Texas "home" may speak to the fact that for centuries Texas has been a shared border, a bridge between the land of "el Norte" and "South of the Border"; it has been a highly contested dividing line between two nation states. Yet the inhabitants of this land often identify themselves as both Texan and Tejano. Daniel Heath Justice believes that these "trans/ national" spaces are where "the critical tributaries come together to nourish and challenge us" (338). Singing the song "Going back to Texas" can be read as the return to a home that bridges and accepts both 
north and south, the individual and the community, "Going Back to Texas," Nis Bundor, and the igariddoged all operate to affirm the culture of a people who laugh, cry, and continue to share their stories of crossing borders north and south

The song also questions the stereotypical identities based on belonging to a group of people. The Texas cowboy is often privileged as the symbol of the United States. Just as the tobacco-spitting, 10-gallon-hat-wearing, rough, tough, pistol-waving lasso-spinning cowboy does not represent every United States citizen, Lisa Mayo and Gloria Miguel do not fit the preconceived notions of either a Guna or a United States born citizen. "Going Back to Texas" reminds audience members once again of those "misidentified, mislabeled and misrepresented" identities performed and entangled with the various geographical locations, cultural practices and ideological borders of the Americas

What Lisa Mayo and Gloria Miguel do affirm through the staging of different elements of the iddogednega in Nis Bundor is their commitment to both the Guna community and the Indigenous community as a whole. Both sisters recognize their Guna heritage as an important factor in the shaping of their identities and emphasize the plurality of voices and paths that are forged from within the larger Indigenous community. Nis Bundor provides Lisa Mayo and Gloria Miguel the creative space to tell their stories and share others in order to perceive new ways of understanding and paths to healing.

Indigenous artists often forge creative roads that leap over and reinterpret the political, cultural and ideological borders previously drawn up without their input. Anishinaabe artist Rebecca Belmore is a member of the Lac Seul First Nation, born in Upsala, Ontario, Canada. Belmore has been called one of "the most consistently productive and provocative Native North American artists over the past twenty years" (Townsand-Gault 721), someone who has "consistently nailed moments of crisis in public debates in Canada" (Townsand-Gault 727). She is internationally recognized for her performance art, especially after being chosen to represent Canada at the 2005 Venice Biennial $51^{\text {st }}$ International Art Exhibition, where she debuted a performance-based video installation entitled "Fountain."

Like so many of Belmore's site-specific works, "Fountain" was a powerful and provocative response to the venue itself. As Lee Ann Martin notes in her piece on Belmore's Venice Biennale installation in Canadian Art, the "Venice Biennale dates from1895, in the era of the great world fairs. These large international expositions were developed as opportunities for both the exchange of ideas and the patriotic display of artistic and technological innovation." The fairs were also sites of "ethnological" displays of nonwhite bodies orchestrated by anthropologists and businessmen. In "Fountain," Belmore is filmed on an industrial beach between the Musqueam Nation and the Vancouver International Airport. Belmore struggles through the waters to the beach, eventually hauling a bucket onto the beach, and heaves the contents toward the camera and thus the viewers. Red covers the screen, as the water turns to a red liquid and we see Belmore standing behind what appears to be a wall of blood. Martin sees the bloodied surface of the screen as recalling "the words of Martin Luther King, Jr. on the Civil Rights Memorial in Montgomery, Alabama: '...until justice rolls down like waters and righteousness like a mighty stream," but she also sees Belmore's action in hurling the bucket of red as "fling[ing] responsibility for the cycles of bloodshed found within the history of colonialism in the Americas back to their European source. Through her actions, an Anishinabe woman from northwestern Ontario recognizes the blood of all the people who suffer because of others' greed for power" (Martin). Like the suaribed who wakes up the members of the igariddoged, Belmore uses her power as a performance artist, in part, to wake the viewer up to the realities she wants us to see. In "Fountain," the entangled geographical locations of the Venice Biennale and the industrialized landscape of the beach in Vancouver invite us to read multiple political contexts into the bucket of "blood" she flings at the camera.

In her earlier Rising to the Occasion, part of a mixed media performance in Twelve Angry Crinolines from July 17, 1987, Rebecca Belmore creates a multilayered, intertextual work that responds to a particular political issue of the moment as well as to a long term political 
one. When Prince Andrew and his (then) new wife Sarah Ferguson were to visit the city of Thunder Bay, Ontario in July 1987, twelve women interpreted an "angry crinoline" and participated in a silent parade down the streets. Belmore's bustle cage crinoline, formed to resemble a beaver lodge, sticks out from the back of her long dress. The beaver house represents Canada, with

little trinkets and trade goods stuck in the beaver lodge with pictures of Lady $\mathrm{Di}$ and Prince Charles with bits of birchbark woven into the [bramble]. And the headpiece is two braids, which are sticking up just to signify the anger [laughs] and the wheel is my umbrella-the invention of the wheel, civilization - and there's two fine bone china breastplates on the chest [laughs]. (Ryan, 211)

The trinkets and trade goods, the pictures of Lady Di and Prince Charles and the broken bone china all serve to remind viewers of the problematic social and economic history of relations between Indigenous peoples and Europeans, a history made visible in a dress constructed from "the wreckage of British colonialism" (Moser). "Rising to the Occasion" plays off the "Indian princess" trope that persists as one of the most common of the "misidentified, mislabeled, and misrepresented" forms of Indigeneity in the Americas.

Indeed, Thomas King reminds us that the only Indians visible to mainstream Americans are "Dead Indians": "the stereotypes and clichés that North America has conjured up out of experience and out of its collective imaginings and fears. War bonnets, beaded shirts, fringed deerskin dresses, loincloths, headbands, feathered lances, tomahawks, moccasins, face paint and beaded chokers. Dead Indians" (King 54). Not only are "Dead Indians" used to sell commercial products (Winnebago Motor Homes, Jeep Cherokee vehicles, Calumet Baking Soda and more) and to promote professional sports teams (Atlanta Braves, Cleveland Indians and Washington Redskins), but they are also repurposed by Indigenous authors who engage with "the tangle of aestheticized politics and desire" (Townsend-Gault, Have We Ever Been Good?).

Belmore takes up the stereotypes of fringed dresses and beaded shirts in her 2008 "Fringe." The life-sized photograph in the form of a lightbox transparency features a dark-haired woman lying on her left side on a white cloth, her back toward the viewer, her head on a white pillow, with a white cloth (matching that of the pillow) draped over the hips and buttocks. Crossing her back, from her right shoulder down to her left hip, is a fringed scar. The fringe has been read as "dripping blood [which] forms a red fringe that is mimicked by white suturing threads" (Bear Robe) or as "a surreal and terrifying use of traditional native beadwork" (Buium); it is the complexity and tensions of Belmore's work, the imbrication and interplay of beauty, violence, politics, the claiming and reclaiming of space, that challenges viewers to rethink their own stereotypes of Native women and Native artists.

For as Saulteaux artist and curator Robert Houle, in writing of Aboriginal artists, reminds us: "Somehow we are not allowed to come into the $20^{\text {th }}$ century. We are not allowed to interpret our own reality; the way our communities respond to everyday life. We are regarded as living museum pieces. This is perpetuated by even the most lavish, most knowledgeable, professional representations of our cultural heritage" (60). Houle's words and Belmore's perfomances, like those of Spiderwoman Theater, underscore that for Indigenous artists it is not just a question of "how you look at it, what you call it and how you live it," but also who gets to call it. When others name their experiences, interpret their realities, they are seen as "living museum pieces." Spiderwoman Theater and Rebecca Belmore challenge the representations of Native cultural heritage put forth by others. Their installations and performances require us to confront the complexities of how Indigenous identities are represented in the Americas, recognizing that any concept of Indigenous identity changes depending on "how you look at it, what you call it and how you live it."

\section{Note}

1. For more on this story, see "Olonadili" as told by Cacique Leonidas Valdez in Pab Igala: Historias de la Tradición Kuna (1989). 


\section{Works Cited}

Abbot, Larry. "Spiderwoman Theatre and the Tapestry of Story. The Canadian Journal of Native Studies. 16 (1996): 165-80.

Belmore, Rebecca. "Rising to the Occasion." 1987. Web. April 27, 2014. <http://www.rebeccabelmore.com/ exhibit/Rising-to-the-Occasion.html.>

Bear robe, Amber-Dawn. "Rebecca Belmore's Performance of Photography." Aboriginal Curatorial Collective. Web. May 1, 2014.

Buium, Greg. "Body Language: Artist Rebecca Belmore's New Vancouver Exhibition Showcases Her Startling Work." CBC News. July 8, 2008. Web. May 1, 2014.

Chapin, Mac. Pab Igala: Historias de la Tradición Kuna. Quito: Ediciones Abya Yala, 1989.

Deloria, Vine Jr. "Sacred Lands and Religious Freedom," American Indian Religions (1994) 1: 75-76.

Fast, Robin Riley. The Heart as a Drum: Continuance and Resistance in American Indian Poetry. Ann Arbor: University of Michigan Press, 1999.

Houle, Robert. "The Struggle Against Cultural Apartheid." CCCA Canadian Art Database. Web. 12 Dec 2014. $<$ http://ccca.concordia.ca/c/writing/h/houle/hou003t. html>.

Hurlbutt, Jerri. "Secrets: A Conversation with Lisa Mayo of Spiderwoman Theatre." Women \& Performance: A Journal of Feminist Theory. 5.2 (1992): 166-83.

Justice, Daniel Heath. "Currents of Trans/national Criticism in Indigenous Literary Studies." American Indian Quarterly. 35.3 (2011): 334-52.

King, Thomas. The Inconvenient Indian: A Curious Account of Native People in North America. Doubleday Canada, 2012. Print.

Martin, Lee Ann. "From the Archives: Rebecca Belmore at the 2005 Venice Biennale." Canadian Art. May 9, 2013. Web. April 27, 2014. <http://www.canadianart. $\mathrm{ca} /$ features/2013/05/09/rebecca-belmore-at-the-2005biennale/.>

Mcleod, Neal. "Coming Home Through Stories." In Addressing Our Words: Aboriginal Perspectives on Aboriginal Literatures, ed. Armard Garnet Ruffo. Penticton, BC: Theytus Books, 2001. 17-36.

Cree Narrative Memory: From Trends to Contemporary Times. Saskatoon: Purich Publishing, 2007. Print.

Moser, Gabrielle. "Rebecca Belmore: Rising to the Occasion." Canadian Art. July 24, 2008. Web. April 27, 2014. < http://www.canadianart.ca/reviews/2008/07/24/ rebecca-belmore/>
Oran, Reuter, and Aiban Wagua. Gayamar Sabga: diccionario escolar gunagaya-español. Panama: Equipo EBI Guna, 2010. Print.

Ortiz, Simon J. Foreword. American Indian Literary Nationalism. Jace Weaver, Craig S. Womack and Robert Warrior (Eds.). Albuquerque: U of New Mexico Press, 2005. vii-xiv.

Ryan, Allan J., ed. The Trickster Shift: Humour and Irony in Contemporary Native Art. UBC Press, 1999. Print.

Shanley, Kathryn W. "Born from the Need to Say': Boundaries and Sovereignties in Native American Literary and Cultural Studies." Paradoxa (2001) 6: 15. 3-26. Print.

Sherzer, Joel. "Kuna Language and Literature." The Art of Being Kuna: Layers of Meaning among the Kuna of Panama. Ed. Mari Lyn Salvador. Los Angeles: UCLA Fowler Museum of Cultural History, 1996. 103-35. Print.

Spiderwoman Theatre. "Nis Bundor". Hemispheric Institute Digital Video Library. New York University, 2008. Web. 7 Jun 2013. <http://hidvl.nyu.edu/ video/000561670.html>.

Taylor, Diana. "Remapping Genre through Performance: From 'American' to 'Hemispheric' Studies." PMLA (2007): 1416-1430. Print.

Tinker, George. "An American Indian Theological Response to Ecojustice." In Defending Mother Earth: Native American Perspectives on Environmental Justice, ed. Jace Weaver. Maryknoll, New York: Orbis Books, 1996. 153-176. Print.

Townsend-Gault, Charlotte. "Rebecca Belmore and James Luna on Location at Venice: The Allegorial Indian Redux. Art History 29.4 (2006): 721-755. Web. 1 May 2014.

"Have We Ever Been Good? Rebecca Belmore: The Named and the Unnamed." The Morris and Helen Belkin Art Gallery, University of British Columbia, 2002.

Treat, James, ed. Native and Christian: Indigenous Voices on Religious Identity in the United States and Canada. Psychology P, 1996. Print.

Weaver, Jace. That the People Might Live: Native American Literatures and Native American Community. New York, NY: Oxford U P, 1997. Print.

Recebido em: 30/05/2014 Aceito em: 03/07/2014 